University of Wollongong

Research Online

Faculty of Law, Humanities and the Arts Papers (Archive)

$1-1-2013$

Revisiting securities regulation in the aftermath of the global financial crisis: disclosure - Panacea or Pandora's Box?

S M. Solaiman

University of Wollongong, sheikh@uow.edu.au

Follow this and additional works at: https://ro.uow.edu.au/lhapapers

Part of the Arts and Humanities Commons, and the Law Commons

Research Online is the open access institutional repository for the University of Wollongong. For further information contact the UOW Library: research-pubs@uow.edu.au 


\title{
Revisiting securities regulation in the aftermath of the global financial crisis: disclosure - Panacea or Pandora's Box?
}

\begin{abstract}
The United States introduced federal securities regulation by adopting the Disclosure-Based Regulation (DBR) in 1933 resembling the doctrine of caveat venditor (DCV) as a substitute for the doctrine of caveat emptor (DCE) in the securities market. The overarching objective of the DBR was to protect investors by enabling them to make 'informed decisions'. Although the change aimed to protect investors, the causes of the GFC suggest that the DCV exists only in theory, while issuers of securities are still enjoying the benefits of the DCE in practice. Financial innovations that intend to camouflage the risks inherent in the complex derivative products should be strictly regulated through a merit regulation which should be applied to only public offers, and the DBR should still remain in force for other securities. It concludes that the DBR has now emerged as more a 'Pandora's box' than a panacea.
\end{abstract}

\section{Keywords}

era2015, financial, global, securities, disclosure, panacea, revisiting, pandora, box, aftermath, regulation, crisis

Disciplines

Arts and Humanities | Law

\section{Publication Details}

S. M. Solaiman, 'Revisiting securities regulation in the aftermath of the global financial crisis: disclosure Panacea or Pandora's Box?' (2013) 14 (4) Journal of World Investment \& Trade 646-671. 


\title{
Revisiting Securities Regulation in the Aftermath of the Global Financial Crisis: Disclosure - Panacea or Pandora's Box?
}

\begin{abstract}
The United States introduced federal securities regulation by adopting the Disclosure-Based Regulation (DBR) in 1933 resembling the doctrine of caveat venditor (DCV) as a substitute for the doctrine of caveat emptor (DCE) in the securities market. The overarching objective of the DBR was to protect investors by enabling them to make informed decisions'. Although the change aimed to protect investors, the causes of the GFC suggest that the DCV exists only in theory, while issuers of securities are still enjoying the benefits of the DCE in practice. Financial innovations that intend to camouflage the risks inherent in the complex derivative products should be strictly regulated through a merit regulation which should be applied to only public offers, and the DBR should still remain in force for other securities. It concludes that the DBR has now emerged as more a 'Pandora's box' than a panacea.
\end{abstract}




\section{Revisiting Securities Regulation in the Aftermath of the Global Financial Crisis: Disclosure - Panacea or Pandora's Box?}

\section{S M Solaiman*}

\section{Introduction}

Disclosure is widely believed to be the most favourable philosophy of securities regulation. Hence, broadening the disclosure requirements is a common measure to restore public confidence which was otherwise shattered by a financial crisis, and securities regulators, if ever, rarely reduce these requirements. ${ }^{1}$ In the aftermath of the recent global financial crisis (GFC), several measures have been taken to strengthen regulation, one of which is again increasing corporate disclosures to the investing public. ${ }^{2}$ Commenting on the reforms made so far around the world, Arner argues that, "while much has been achieved to date, the postcrisis international regulatory reforms that have been adopted would not have prevented the global financial crisis, nor are they sufficient to lay the foundations for future global financial stability' ${ }^{3}$

Despite the prevalence of the disclosure-based regulation (DBR), not only ordinary investors, but their institutional counterparts such as banks and many other financial companies have unprecedentedly lost huge value in their investments in a very short period of time. ${ }^{4}$ Thus the GFC manifestly demonstrates that not only small retailers, but the large institutional investors are 'vulnerable to irrational exuberance and, at times, outright fraud'

* Dr S M Solaiman, PhD (University of Wollongong), LLM (University of Western Sydney), LLM (University of Dhaka), LLB Hons (University of Rajshahi) is a Senior Lecturer, School of Law, University of Wollongong, NSW, Australia. The author can be contacted at sheikh@uow.edu.au. He wishes to acknowledge the funding for this research provided by Legal Scholarship Support Scheme, NSW, Australia.

${ }^{1}$ Stephen J Choi and A C Pritchard, 'Behavioural Economics and the SEC' (2003) 56 Stanford Law Review 1, 47-48.

${ }^{2}$ For a detailed account of important reforms made by the international community, see Douglas W Arner, 'Adaptation and Resilience in Global Financial Regulation' (2011) 89 North Carolina Law Review 1580, 158795.

${ }^{3}$ Ibid, 1583.

${ }^{4}$ See for details, Philipp M Hildebrand, 'The Sub-prime Crisis: A Central Banker's Perspective' (2008) 4 Journal of Financial Stability 313. 
and to the risks embedded in the complex financial products. ${ }^{5}$ Consequently, national and international economies have suffered a serious blow from the GFC. The crisis led to the downfall of several governments across the Europe. Quite simply, the destruction caused by the crisis is enormous, and this is the largest economic meltdown ever since the devastating recession of the 1930s. In January 2012, the International Monetary Fund warned the world community of an impending disaster like the great depression of the 1930s unless Europe's debt crisis is resolved. ${ }^{6}$

There are conflicting views about the recurrence of the GFC. Some commentators say that regulation has nothing to do with the reappearance of such a crisis after a long interval, ie, it is inevitable. ${ }^{7}$ However, others believe that the desolation could have well been prevented had effective regulatory measures been put in place to deal with the actors and factors playing in the US housing and financial markets. ${ }^{8}$ Both sides of the strife may have conceivable arguments for their competing assumptions, but that debate falls beyond the scope of this study. Evidently, the debacle of the financial markets in the developed world is linked to the irregularities in the US housing market in which unscrupulous lenders took unreasonably excessive risks relying on the transferability of those risks to investors through securitisation.

The financial market is basically a bridge between issuers of, and investors in, financial products, all of which almost invariably bear risks at a varying degree. The regulatory role is to contain those risks by preventing them from inflicting systemic damage to the financial

\footnotetext{
${ }^{5}$ Saule T Omarova, 'The New Crisis for the New Century: Some Observations on the "Big-Picture" Lessons of the Global Financial Crisis of 2008' (2009) 13 North Carolina Banking Institute 157, 161.

6 Sue Lannin, "World Shares Mixed as Investors Eye Greece" ABC News (24 Jan 2012) http://www.abc.net.au/news/2012-01-24/world-shares-close-mixed/3789840.

${ }^{7}$ See Alex Pollock, 'Regulatory Implications of the Housing and Mortgage Bubble and Bust' Global Macro EconoMonitor (11 Jul 2008) < http://www.economonitor.com/blog/2008/07/regulatory-implications-of-thehousing-and-mortgage-bubble-and-bust/ $>$.

${ }^{8}$ See John C Coffee, Jr, "What Went Wrong? An Initial Inquiry into the Causes of the 2008 Financial Crisis' 9 (2009) 9 Journal of Corporate Law Studies 1.
} 
system as a whole. ${ }^{9}$ A market disaster takes place when the regulators fail to effectively play its due role to contain the creation, distribution and assumption of excessive risks inherent in complex derivative products by different players in the market. ${ }^{10}$ This study endeavours to find ways of making the regulation more effective in protecting investors as well as their issuers from excessive risk-taking.

This paper, in pursuit of a more appropriate regulatory method, aims to critically examine the usefulness of the disclosure philosophy in respect of complex derivative financial products which contributed extensively to the GFC. This article opposes neither the proliferation of such products nor the disclosure as a useful regulatory philosophy. Rather it intends to evaluate the effectiveness of the DBR in terms of making informed investment decisions based on merely issuers' disclosures to the public. It concludes that the exceeding complexities of derivative products, such as mortgage-backed securities (MBSs), assetbacked securities (ABSs) or collateral debt obligations (CDOs), coupled with the behavioural constraints of investors, have rendered the DBR ineffective in helping investors to make informed decisions. It also argues that the regulation of securities issuers alone may not proffer any touchstone to eliminate the possibility of recurrence of such a downturn in the future, investors should also be brought under some sort of regulatory oversight through imparting investment education. This arises from serious concern of behavioural finance which is deeply rooted in the process of economic bubble and bust in which investors generally do not exercise due diligence in buying toxic securities and they become overly relied upon rating agencies. ${ }^{11}$

\footnotetext{
${ }^{9}$ Julia Black, 'Rebuilding the Credibility of Markets and Regulators' (2009) 3 Law and Financial Markets Review 1, 1.

${ }^{10}$ For a detail discussion of this complexity, see Steven L Schwarcz, 'Regulating Complexity in Financial Markets' (2009) 87 Washington University Law Review 211.

${ }^{11}$ Black, above n 9, 2.
} 


\section{Causes of the Global Financial Crisis}

To date much has been written about the GFC and its contributing causes. ${ }^{12}$ Instead of conducting a further investigation into the causes of the crisis, this article picks up some of the main causes from the existing literature for the discussion of the effectiveness of the disclosure regime as a regulatory philosophy for securities markets. A detailed analysis of these causes is therefore beyond the scope of this endeavour.

An economic catastrophe is, as observed by Coffee, much like Tolstoy's unhappy marriages and each of them emerges in a distinctive way. ${ }^{13}$ Although every financial crisis may have its own unique features, however, a very high optimism precedes perhaps all crises as a common precursor. ${ }^{14}$ A single factor by no means can be blamed for this crisis. ${ }^{15}$ It is a by-product of several failures of different constituencies in the housing and financial markets. The crisis is basically a sour outcome of credit bubble and bust. Coffee describes this bust as a product of supply driven bubble. ${ }^{16}$

Although there are several causes of the GFC such as: moral hazards in the securitisation process, poor underwriting standards for subprime mortgage, poor credit rating practices especially in relation to MBSs and ABSs, excessive risk taking and weak risk management

\footnotetext{
${ }^{12}$ See, for example, Coffee, above n 8, 1; Douglas W Arner, 'The Global Credit Crisis of 2009: Causes and Consequences' (2009) 43 The International Lawyers 91; Dorit Samuel, 'The Subprime Mortgage Crisis: Will New Regulations Help Avoid Future Financial Debacles?' (2009) 2 Albany Government Law Review 217; Kenneth W Dam, 'The Subprime Crisis and Financial Regulation: International and Comparative Perspectives' (2010) 10 Chicago Journal of International Law 581; Emilios Avgouleas, 'The Global Financial Crisis, Behavioural Finance and Financial Regulation: In Search of a New Orthodoxy' (2009) 9 Journal of Corporate Law Studies 23; Gerry Gallery and Natalie Gallery, 'Rethinking Financial Literacy in the Aftermath of the Global Financial Crisis' (2010) 19 Griffith Law Review 30.

${ }^{13}$ Coffee, above $n 8,1$.

${ }^{14}$ See Arner, above $\mathbf{n} 12$.

${ }^{15}$ See Arner, above n 12; George A Walker, 'Financial Crisis - U.K. Policy and Regulatory Response' (2010) 44 The International Lawyer 751.

${ }^{16}$ Coffee, above $\mathrm{n} 8,1$.
} 
by financial institutions in developed countries, and regulatory failures in overseeing the above causes, ${ }^{17}$ this study is focused on mainly the first and last ones.

Avgouleas asserts that the major cause is said to be an atypical expansion of credit leading to the global financial system to an untenable levels of gearing. ${ }^{18}$ This expansion resulted from stable low interest rates, the rapid proliferation of debt financial products, and the momentous increase of institutional investors who injected huge amounts of money into the global capital markets. ${ }^{19}$ Subprime mortgage loans and the securitisation of those loans played a central role in the fiasco. ${ }^{20}$ Subprime mortgage defaults started rising in early 2006 and came to a head in $2007 .^{21}$ The crisis quickly spread over the other segments of the financial market around the world relying on economic globalisation and securitisation, as MBSs and ABSs had been distributed at large throughout the developed economies.

Given the demographic development over time in the US, it is reasonable that the prices of real estate would go up, but the boom would not have taken place without the growth of subprime mortgages which rose from $6 \%$ in 2001 to $15 \%$ in $2006 .^{22}$ The loan originators had granted these mortgage loans with a plan to quickly transfer the risk of defaults to 'uninformed' voracious investors in the securities market. ${ }^{23}$ Therefore, the loan originators deeply relied upon securitisation. ${ }^{24}$ This massive securitisation of huge junk debts was possible due to the regulatory reliance on the disclosure philosophy which allows any securities to be issued to the public regardless of their actual merits by disclosing

\footnotetext{
${ }^{17}$ See, for several causes of the GFC, Coffee, above n 8; Avgouleas, above n 12; Walker, above n 15; Arner, above $\mathrm{n} 12$.

${ }^{18}$ Avgouleas, above n 12, 34 .

${ }^{19}$ Ibid.

${ }^{20}$ See, for details, Josef Ackermann, 'The Subprime Crisis and Its Consequences" (2008) 4 Journal of Financial Stability 329.

${ }^{21}$ Ibid, 330 .

22 Ibid.

${ }^{23}$ See Raymond H Brescia, 'Part of the Disease or Part of the Cure: The Financial Crisis and the Community Reinvestment Act' (2009) 60 South Carolina Law Review 617, 621.

${ }^{24}$ Peter L Swan, 'The Political Economy of the Subprime Crisis: Why Subprime Was So Attractive to Its Creators' (2009) 25 European Journal of Political Economy 124, 130.
} 
comprehensively all material information to the market. Both the regulators and issuers have largely ignored the investors' ability to understand, and their real need for, such a disclosure. At the same time, investors themselves did not care much about the disclosure due to either their inability to comprehend the lengthy and complex 'disclosure document" ${ }^{25}$ or their overconfidence about profits from their investments. This is where the problem lies.

Schwartz blames mostly the lending policy and explains that:

The credit crisis was propagated by securitisation and especially the substitution of the 'originate to distribute' model of bank lending in view of the traditional 'originate to hold' model. These banking or lending innovations and notably the practice of the derivatives industry made the problem worse. ${ }^{26}$

The boom in the US housing markets and excessive liquidity in the global financial markets are regarded the two most interrelated and influential factors. ${ }^{27}$ Excessive liquidity in the market made the market players overconfident about the prevalence of strong performance of the market in the future. The loan originators took advantage of this financial euphoria in creating and marketing innovated debt products. Interest rates were low and underwriting standards were poor. Subprime lenders provided loans to those with dubious credit histories and these poor credit-record borrowers pushed the housing prices up. The lenders then securitised the loans and transferred the risks to innocent investors. Institutional investors borrowed money from banks and bought those toxic financial products aiming to diversify their portfolios. This is how the risk inherent in the securitised products bounced back to the banks that provided loans. As long as the housing prices experienced an upward trend, the borrowers refinanced the equity for other household items and the lenders were happy to extend the credit. They failed to repay the loans when the interest rate increased causing declines in housing prices. Meanwhile the defaulted mortgages became part of the toxic

\footnotetext{
25 'Disclosure document', 'prospectus' and 'disclosure' are interchangeably used in this article, though they may have different meanings in a particular jurisdiction such as in the USA.

${ }^{26}$ As quoted in Norman Gall, 'Financial Assets and World Economy - Money, Greed, Technology' (2008) 42 Braudel Papers 1, 7.

${ }^{27}$ Ackermann, above n 20, 330.
} 
structured products held by both institutional and general securities investors. Thus the losses associated with those mortgages spread throughout the financial system. This is how the losses of the housing market had been shared by the hedge funds, general investors and financial institutions including banks and institutional investors. ${ }^{28}$ Investors suddenly rushed to offload their investments in a bearish and illiquid market, which results in a crash in the prices of securities.

There is no denying the fact that loan originators lacked due diligence in assessing a loan application especially in respect of a sub-prime borrower. The lenders, in defiance of the historical practice of carefully checking potential borrowers' credit records, largely ignored the borrowers' ability to repay their loans. ${ }^{29}$ The lenders sold off their loans and consequently credit standards declined to the infamous extreme of NINJA (No Income, No Job and Assets) loans to US subprime borrowers. ${ }^{30}$

Investors were not supplied with adequate information about the quality of underlying assets. $^{31}$ The issuers of the products used a very complicated formula in pricing those products. Even the subprime borrowers, let alone the investors in such MBSs, were unlikely to be able to properly ascertain the value of risks they assumed due to their lack of sophistication. $^{32}$

Investors generally are not able to assess the actual worth of the securitised products because of the inherent complexity of those derivatives. They usually rely on the credit ratings carried out by the apparently credible rating agencies. Hence investors relied on those

\footnotetext{
${ }^{28}$ See for greater details, Avgouleas, above n 12, 37.

${ }^{29}$ Avgouleas, above n 12, 39.

${ }^{30}$ John Kiff and Paul Mills, 'Money for Nothing and Checks for Free: Recent Developments in U.S. Subprime Mortgage Markets' (Working Paper WP/07/188) International Monetary Fund, 2007.

${ }^{31}$ Susanna Kim Ripken, 'The Danger and Drawback of the Disclosure Antidote: Toward a More Substantive Approach to Securities Regulation' (2006) 58 Baylor Law Review 139, 186.

${ }^{32}$ Avgouleas, above n 12, 44.
} 
agencies in the valuation of these products. ${ }^{33}$ But the agencies did not seem to be trustworthy with respect to accurate ratings of the debt derivatives which contributed to the GFC. However, an in-depth investigation into the role of credit rating agencies could be a subject matter of another endeavour. This study is concerned with the failure of the DBR to eliminate information asymmetry or communicate material information to help an informed investment decision.

\section{Objectives of Securities Regulation}

The primary objective of securities regulation is to provide protection to the investing public. Securities regulators worldwide are therefore an avowed advocate of "investor' 34 protection, which is the first objective of this regulation as specified by the International Organisation of Securities Commissions (IOSCO). ${ }^{35}$ The second objective is ensuring market fairness, efficiency and transparency in the market operation, whilst reducing systemic risks is the third of the total three objectives as set forth by the IOSCO. ${ }^{36}$ All of these objectives are directly or indirectly related to investor protection.

Several empirical studies suggest that there has been a strong correlation between investor protection and the development of securities markets. A group of writers namely, La Porta, Lopez-De-Silanes, Shleifer and Vishny (LLSV) have presented a significant amount of

\footnotetext{
${ }^{33}$ Stephen Foley, 'US Fed Rides to the Rescue of AIG with 85 bn Bail-Out' The Independent (18 Sep 2008) UK.

${ }^{34}$ In terms of the whole securities regulation, investors generally include creditors as well.

${ }^{35}$ For details of the objectives, see International Organisation of Securities Commissions (IOSCO)

Objectives and Principles of Securities Regulation (May http://www iosco.org/library/pubdocs/pdf/IOSCOPD154.pdf.

${ }^{36}$ Systemic risks are associated with the secondary market as described by the IOSCO. Thus this objective falls outside the purview of this study. For details, see International Organisation of Securities

Commissions (IOSCO) Objectives and Principles of Securities Regulation: A Report of the International

Organisation of Securities Commission (Sep 1998) <http://www.iosco.org/doc-public/1998-objectivesdocument01.hmtl>.
} 
literature in connection with investor protection that is often cited in contemporary research in this area. ${ }^{37}$

The regulators aim to facilitate this protection through minimisation of informational asymmetry between the issuers and their potential investors. It may be appropriate to say that securities regulation is simply the regulation of information asymmetry for the purpose of mainly protecting the investing public.

Historically, it is true that investors are not able to protect themselves. ${ }^{38}$ This view is strongly supported by a 2001 survey which revealed that 'investors would be hopelessly idiotic if they relied on themselves'. ${ }^{39}$ This claim has been reinforced by the recent debacle of capital markets around the world during the GFC and the unprecedented massive securities frauds perpetrated by Bernard Madoff. ${ }^{40}$ Therefore, the investors need government protection which should militate against the commission of fraudulent and dishonest acts by other market actors.

\section{Importance and Effectiveness of Disclosure as a Regulatory Philosophy}

Although the securities regulation originated in the UK, the United States significantly contributed to popularising this regulation. The US inherited both the English concept of securities regulation and the idea of securities markets. ${ }^{41}$ Initially, the US federal government

\footnotetext{
${ }^{37}$ See Rafael La Porta, Florencio Lopez-de-Silanes, and Andrei Shleifer , 'What Works in Securities Law' (2006) 61 Journal of Finance 1; Rafael La Porta et al, 'Investor Protection and Corporate Valuation' (2002) 57 Journal of Finance 1147; Andrei Shleifer and Daniel Wolfenzon, 'Investor Protection and Equity Markets' (2002) 66 Journal of Financial Economics 3; F Lopez-De-Silanes, 'The Politics of Legal Reforms' (2002) 2 Economia 91; Rafael La Porta et al, 'Investor Protection and Corporate Governance' (2000) 58 Journal of Financial Economics 3; Rafael La Porta et al, 'Agency Problems and Dividend Policies Around the World' (2000) 55 Journal of Finance 1; Rafael La Porta and Florencio Lopez-de-Silanes, 'Corporate Ownership Around the World' (1999) 54 Journal of Finance 471; Rafael La Porta, Florencio Lopez-de-Silanes, and Andrei Shleifer, 'Law and Finance' (1998) 106 Journal of Political Economy 1113; Rafael La Porta et al, 'Legal Determinants of External Finance' (1997) 52 Journal of Finance 1131; Andrei Shleifer and Robert W Vishny, 'A Survey of Corporate Governance' (1997) 52 Journal of Finance 737.

${ }^{38}$ See M H Cohen, “"Truth in Securities" Revisited' (1966) 79 Harvard Law Review 1340, 1351-52.

${ }^{39}$ See 'Investor Ignorance' Investment News (6 Aug 2001) 4.

${ }^{40}$ Janet Morrisssey, 'The Penalty for "Extraordinary Evil": Madoff Gets 150 Years' The Time (29 Jun 2009), $1<$ http://www.time.com/time/business/article/0,8599,1907677,00.html>.

${ }^{41}$ Stuart Banner, Anglo-American Securities Regulation: Cultural and Political Roots 1690-1860 (1998)
} 
did not show any concern about securities regulation which was first introduced at the state level. The first 'state securities law' which is commonly referred to as 'blue sky law' ${ }^{42}$ was enacted in Kanas in $1911,{ }^{43}$ which adopted a philosophy of the 'merit regulation' of proposed public offers. This merit regulation was gradually adopted by almost all US states. The US Supreme Court observed in Hall v Gieger-Jones Co that the blue-sky laws were enacted to protect investors from promoters who would engage in selling stock in the blue sky itself. ${ }^{44}$

Federal securities law came into being in the aftermath of the great depression of 1929 with the enactment of the Securities Act $1933 .^{45}$ The US federal regulation was put in place as supplementary to the existing state regulation from a different philosophical standpoint, which was based on disclosure. The US adoption of the disclosure philosophy paved the way of today's widespread use of this sophisticated method of regulation for the securities market.

\section{Salient Features of the Disclosure-Based Regulation}

The importance of disclosure is profound in securities trading because every bit of material information may affect an investment decision. A lack of disclosure shatters investor confidence which may eventually trigger a market crash because of uninformed and imprudent investment decisions by investors. This is consistent with the primary objective of corporate disclosure in that it allows the investing public to make informed and prudent investment decisions where disclosures are full, fair and clearly understood by the investors or their financial advisers. The DBR as the substitution for the philosophy of caveat emptor for financial products was introduced aiming at achieving 'a high standard of business ethics in the securities industry' as illustrated by the US Supreme Court on several occasions. ${ }^{46}$ It is

Cambridge: Cambridge University Press, 122. See also, Louis Loss, Fundamentals of Securities Regulation $\left(2^{\text {nd }}\right.$ ed, 1988) Boston: Little, Brown and Company $1,3$.

42 'Blue Sky Laws' aimed to regulate 'speculative schemes which have no more basis than so many feet of blue sky': Hall v Gieger-Jones Co 242 US 539, 550 (1917).

${ }^{43}$ Loss, above $n 41,8$.

242 US 539, 550 (1917).

${ }^{45}$ Loss, above $\mathrm{n} 41,1$.

${ }^{46}$ SEC v Capital Gains Research Bureau Inc 375 US 180, 186 (1963); Affiliated Ute Citizens of Utah v United States 406 US 128, 151 (1972). 
a major concern of this article to examine whether or not this substitution has taken place in practice.

As opposed to the merit-based regulation (MBR), the DBR relies on making 'full and fair disclosure' to the investing public. It means the DBR differs fundamentally from the MBR in that it (DBR) allows any company regardless of merits of the offer to go public if it discloses all pieces of material information necessary to make informed investment decisions. The only requirement under the DBR is to comply with the disclosure requirements instead of fulfilling any threshold 'qualifications' or 'fitness' that may be required under the merit regime. The role of securities regulator is limited to overseeing, rather than to ensuring, that all pieces of material information are embodied in the disclosure document. The onus of the assessment of investment merits of a particular offer is left to the potential investors themselves irrespective of their actual ability to do so. The regulator, in fact, takes no responsibility whatsoever for the inherent weaknesses of an offer, and such a disclaimer is generally published in the disclosure document with high importance.

\section{Effectiveness of Disclosure as a Regulatory Philosophy}

It is agreeable that the DBR may proffer certain advantages for securities regulation such as the reduction of information asymmetry, the facilitation of informed investment decision, the prevention of frauds and the boosting of investor confidence. ${ }^{47}$ The materialisation of all these benefits depends essentially on the 'full and fair disclosure' by issuers and investors' accurate understanding and processing of the disclosed information. So, both the issuer and the investor have a serious role to play in making the disclosure system effective. Any deficiency on the part of either party may jeopardise the whole purpose of the disclosure system, and such a deficiency seems to exist in almost all public offers in one way or another.

${ }^{47}$ For details, see Ripken, above n 31, 150-55. 
This is so because, ordinary investors generally lack either or both adequate investment knowledge or motivation to correctly process the disclosed information that supposedly imply the suitability of a given public offer. At the same time, many issuers either do not disclose the truth or they disclose necessary information in an ambiguous manner that remains beyond the reach of investors, at least to unsophisticated speculators.

There is ample literature based on market realities suggesting that the benefits of disclosure are counted relying on a flawed assumption of investor's ability and motivation to utilise the information. The proponents of the disclosure philosophy argue that the investing public is generally rational, and that information disclosed to investors provides a rational basis to evaluate securities. ${ }^{48}$ This assumption seems to be flawed. ${ }^{49}$

In appreciation of such a flaw, the DBR, has never been without its critics, although it is perhaps a great invention in securities regulation. Justice Louis D Brandeis ${ }^{50}$ may be called the 'spiritual father' of the Securities Act 1933 which contains the disclosure philosophy, as suggested by Professor Louis Loss. ${ }^{51}$ The DBR in the US is founded on the great assertion of Justice Brandeis who said in 1913 regarding corporate disclosure that '[s]unlight is said to be the best of disinfectants; electric light the most efficient policeman'. ${ }^{52}$ However, he recognised that 'excessive sunlight can cause skin cancer'. ${ }^{53}$ Both the quantity and quality of disclosures may imply that investors today are exposed to 'excessive sunlight' meaning too much and too complicated disclosure. This has been a cause of ruination of numerous investors around the world, and is widely recognised as a stimulating factor of the GFC. Referring to the Australian disclosure regime, Sherry and Tanner submitted to a

\footnotetext{
${ }^{48}$ Alan B Levenson, 'The Role of the SEC as a Consumer Protection Agency (1971) 27 The Business Lawyer 61,62 .

${ }^{49}$ For detail discussion of the flaws of the disclosure philosophy, see Ripken, above n 31, 156-184.

${ }^{50}$ Justice Louis D Brandeis became judge in the US Supreme Court in 1916 and retired in 1939: T K McCraw, Prophets of Regulation (1984) Cambridge: The Belknap Press of Harvard University Press 135.

${ }^{51}$ Loss, above $n 41,32$.

${ }^{52}$ Louis D Brandeis, Other People's Money: And How the Bankers Use It (1933) Washington: National Home Library Foundation 62. It was first published in Harper's Weekly, 1913-1914.

${ }^{53}$ Louis Loss, 'Disclosure as Preventive Enforcement' in K J Hopt and G Teubner (eds), Corporate Governance and Directors' Liabilities (1985) Berlin: Walter de Gruyter 327, 331.
} 
parliamentary committee in 2007 that the disclosures are 'too long, too complex and difficult to understand'. ${ }^{54}$ Referring to the Wallis Financial Inquiry Report 1997 in Australia, Pearson quotes that 'consumers lack (and cannot efficiently obtain) the knowledge, experience or judgment required to make informed decisions' about some products, thus 'further disclosure, no matter how high quality or comprehensive, cannot overcome market failure'. ${ }^{55}$ This came true as evident from the GFC. Such an implication of the DBR was foreseen at its very beginning in the US. ${ }^{56}$ Commenting on the disclosure philosophy entrenched in the Securities Act 1933, Justice Douglas of the US Supreme Court in 1934, a few years before being the chairman of the US Securities and Exchange Commission, said that:

[T]hose needing investment guidance will receive small comfort from the balance sheets, contracts, or compilation of other data revealed in the registration statement. They either lack the training or intelligence to assimilate them and find them useful, or are so concerned with a speculative profit as to consider them irrelevant. ${ }^{57}$

Now the question is whether the objective of facilitation of informed investment decision has

been achieved by the DBR or the culpability of market participants has been fostered instead.

\footnotetext{
${ }^{54} \mathrm{~N}$ Sherry and L Tanner, 'Complexity to be Tackled in Financial Services Working Group to Start Immediately' Media Release No 12 (15 Feb 2008) as cited in Gallery and Gallery, above n 12, 40.

${ }^{55}$ For a good point against disclosure made in the Wallis Report see Gail Pearson, Financial Services Law and Compliance in Australia (Cambridge 2009) 20; : Wallis Report 1997,190.

${ }_{56}$ The debate originated basically following the adoption of the DBR at the federal level in 1933 in the US, whilst the state level securities regulation relied on the merit philosophy. For details of the debate, see Ad Hoc Subcommittee on Merit Regulation of the State Regulation of Securities Committee, 'Report on State Merit Regulation of Securities Offerings' (1986) 41 The Business Lawyer 785; James S Mofsky, 'State Securities Regulation and New Promotions: A Case History' (1969) 15 Wayne Law Review 1401; Homer Kripke, Disclosure: Regulation in Search of a Purpose (1979) New York: Law \& Business Inc; H S Bloomenthal, 'Blue Sky Regulation and the Theory of Overkill' (1969) 15 Wayne Law Review 1447; E W Walker and B B Hadaway, 'Merit Standard Revisited: An Empirical Analysis of the Efficiency of Texas Merit Standards' (1982) 7 The Journal of Corporation Law 651; Mark A Sargent, 'Blue Sky Law: The Challenge to Merit RegulationPart I' (1984) 12 Securities Regulation Law Journal 276; Mark A Sargent, 'Blue Sky Law: The Challenge to Merit Regulation-Part II' (1985) 12 Securities Regulation Law Journal 367; H M Makens, 'Who Speaks for the Investors? An Evaluation of the Assault on Merit Regulation' (1984) 13 University of Baltimore Law Review 435; J T Brandi, 'Securities Practitioners and Blue Sky Laws: A Survey of Comments and a Ranking of States by Stringency of Regulation' (1985) 10 Journal of Corporation Law 689; J T Brandi, 'Merit Securities Regulation, Market Efficiency, and New Issue Stock Performance' (1987) 12.Journal of Corporation Law 699; Alison Grey Anderson, The Disclosure Process in Federal Securities Regulation: A Brief Review (1974) 25 Hastings Law Journal 311; Homer Kripke, The Myth of the Informed Layman (1973) 28 The Business Lawyer 631.

57 Loss, above $\mathrm{n} 53,331$.
} 
This facilitation will be considered in terms of full and fair disclosure by issuers as well as the understanding and utilisation of the disclosed information by investors.

The US disclosure regime is arguably one of the most useful regimes in the world given the level of sophistication of investors, the largeness of issuers, the comprehensiveness of the laws and the resources of regulators. Nonetheless, the US has to accept the blame of being the originator of the GFC triggered chiefly by the failure of their disclosure regime as far as the securities market is concerned. Referring to the corporate collapses over the recent years in the US prior to the GFC, Ripken mentions that investors have suffered large damages following massive accounting irregularities that engulfed several big companies causing "the broad markets to lose trillions of dollars in value and wiped out thousands of jobs and employee pensions' ${ }^{58}$ Taking into account the foul-plays in the securities market under the name of securitisation and selling securitised or collateralised debt products that fueled the GFC, it can be plausibly argued the DBR did not work well even in the US financial market.

\section{Weaknesses of the Disclosure-Based Regulation}

There are significant weaknesses which have rendered the DBR largely ineffective in achieving its objective of investor protection. Some of the important weaknesses are discussed below. ${ }^{59}$

Lengthy and complex disclosure: The disclosure document is too long and exceedingly complex which makes it difficult for ordinary investors to comprehend. Some commentators argued decades ago that the prospectus disclosures in the US were so detailed that many investors were unable to detect even outright fraud solely by reading them. ${ }^{60}$ The length and complexity of the document provide little or no incentive for investors to read it as they find

\footnotetext{
${ }^{58}$ Ripken, above n 31,139-140 (citation omitted).

${ }^{59}$ Weaknesses are largely adopted from: Ripken, above n 31. See also Jose Miguel Mendoza, 'Securities Regulation in Low-Tier Listing Venues: The Rise of the Alternative Investment Market' (2008) 13 Fordham Journal of Corporate Finance 257.

${ }^{60}$ Vincent P Carosso, Investment Banking in America 1970: A History (1970) Cambridge, Mass: Harvard University Press 362.
} 
it inconceivable. An early study found that 'most investors do not read, let alone thoroughly analyse, financial statements, prospectuses, or other corporate disclosures..., ${ }^{, 61}$ This finding is strongly supported by Prentice who observes that investors typically do not look at disclosure documents in making their investment decision. ${ }^{62}$ In a context of commercial contracts, a recent empirical study confirms that consumers do not know the rights and obligations that they assume in a commercial transaction despite adequate disclosures as they do not read the information disclosed to them. ${ }^{63}$ The study also concludes that 'regulators must move beyond disclosure if they wish to take consumer protection seriously' ${ }^{64}$

The worst investment victims of the GFC are the sophisticated investors and experienced institutional buyers as they lost the most. ${ }^{65}$ There is little dispute that disclosures about the securitised products (MBS, $\mathrm{ABS}, \mathrm{CDO}, \mathrm{CDO}^{2}, \mathrm{CDO}^{3}$ etc) which were at the heart of the GFC generally complied with disclosure requirements. ${ }^{66}$ Nonetheless, the complex nature of the products made the disclosure technically or practically insufficient. ${ }^{67}$ The products are so complex that even institutional investors, let alone general investing public, did not understand the risks they assumed by investing in them. ${ }^{68}$ The difficulty is so severe that even financial experts believe that disclosures are incomprehensible and therefore may not be understood by any single person. ${ }^{69}$ So, the victims of the GFC made their investment decision based on the investment grades given by the credit rating agencies instead of fully

\footnotetext{
${ }^{61}$ Baruch Lex and Meiring De Villiers, 'Stock Price Crashes and 10b-5 Damages: A legal, Economic, and Policy Analysis (1994) 47 Stanford Law Review 7, 19.

${ }^{62}$ Robert Prentice, 'Wither Securities Regulation? Some Behavioral Observations Regarding Proposals for its Future (2002) 51 Duke Law Journal 1397, 1456.

63 See Florencia Marotta-Wurgler, 'Does Disclosure Matter?' ( March 2011) , 37 (citation omitted) $<\mathrm{http}$ //www.utexas.edu/law/academics/centers/clbe/wp/wpcontent/uploads/centers/clbe/wurglerdoesdisclosurematter.pdf $>$

64 Ibid.

${ }^{65}$ Steven L Schwarcz, 'Disclosure's Failure in the Subprime Mortgage Crisis' (2008) Utah Law Review1109, 1121.

${ }^{66}$ Ibid, 1113.

${ }^{67}$ Ibid.

${ }^{68}$ Ibid, 1114.

${ }^{69}$ See David Barboza, 'Complex El Paso Partnerships Puzzle Analysis, The New York Times (23 Jul 2002) C1; Karl R Popper and Konrad Lorenz as cited in Schwarcz, above n 65, 1114 (footnote 26).
} 
understanding the long disclosure documents which typically contain hundreds of pages. ${ }^{70}$ Schwarcz asserts that 'the very complexity of securities backed by subprime mortgages makes it difficult to assess their suitability for investment, potentially seducing individuals into seeing what they are already inclined to believe - that these securities are creditworthy. ${ }^{, 71}$

Gilson and Kraakman observed decades ago that the innovative products are so complex and the market needs time to understand the investment suitability of such financial instrument. $^{72}$ Regarding the GFC, Wien, the Chief Investment Strategist, observes that '[e]ven the people running Wall Street firms didn't really understand what they were buying and selling'. ${ }^{73}$ Schwarcz argues that this complexity implies the inherent limitation of disclosure in the securities market, ${ }^{74}$ and he goes on to say that it would be inexpedient to continue to tolerate disclosure as the sole paradigm for remedying the information asymmetry between originators and investors'. ${ }^{75}$

The very function of disclosure is reducing information asymmetry by communicating information about the issuer and the issue to investors. ${ }^{76}$ The aforesaid arguments suggest that disclosure cannot satisfy the purpose of communication of facts and figures about a public offer of securities in order to narrow down, if not eliminate, the information asymmetry. ${ }^{77}$

Further, against the DBR, there was a submission to the US House of Representatives at the time of enactment of securities legislation in 1933 that "even trained accountants are unable to determine, without detailed investigation, the intrinsic value of securities of

\footnotetext{
${ }^{70}$ Schwarcz, above n $65,1114$.

${ }^{71}$ Schwarcz, above n 65,1115 .

72 Ronald J Gilson and Reinier H Kraakman, 'The Mechanisms of Market Efficiency '(1984) 70 Virginia Law Review 549, 568, 585, 615-616.

${ }^{73}$ Byron Wien was quoted in Nelson D Schwartz and Julie Creswell, 'What Created This Monster? The New York Times (23 March 2008) BU1, 8.

${ }^{74}$ Schwarcz, above n 65, 1115 .

${ }^{75}$ Schwarcz, above n 65, 1117.

${ }^{76}$ Levenson, above n 48, 68.

${ }^{77}$ Ripken, above n 31, 185 .
} 
corporations'. ${ }^{78}$ There appears to be a sharp contradiction between the legal requirements of full disclosure and making the disclosure comprehensible to ordinary investors. ${ }^{79}$ Similarly, Ripken argues that recent developments in business have been 'so rapid and gigantic even persons trained in one field are incapable of determining values in a related business'. ${ }^{80}$ Referring to the GFC, Omarova states that risks associated with a financial product itself have transformed to an asset which has been priced and traded between sophisticated market players. ${ }^{81}$ This is true in respect of derivative financial instruments including securitised debt products. Therefore, it cannot be gainsaid that businesses are now more complex than before, and, so are their securities such as securitised financial products which contributed largely to the GFC. The crisis teaches us that '... "slicing and dicing" of financial risk may decrease risk exposure for individual market players, it intends to increase the overall riskiness and vulnerability of the financial system'. ${ }^{82}$ This increase in risks results from the complexity of the products that are incomprehensible to investors.

Insufficiency in material information: In addition to the complexity, insufficiency is said to be another shortcoming of the DBR. A disclosure document is long and full of legal, accounting, economic and financial jargons that are more protective to issuers than their potential investors, and it does not always embody all the necessary information required by investors to accurately determine the suitability of investments. ${ }^{83}$ It has been argued that prospectuses are generally written and revised to avoid liability by the issuers, rather than to communicate the true information to potential investors, and thus disclosures are often presented in technical language and unreadable 'legalese'. ${ }^{84}$ When the drafters of the disclosure primarily aim to comply with the legal requirements and thereby avoid liability by

\footnotetext{
${ }^{78}$ Ripken, above $\mathrm{n} 31,186$ (citation omitted).

${ }^{79}$ Levenson, above n 48, 68 .

80 Ripken, above n 31, 186.

81 Omarova, above n 5, 162.

82 Ibid.

83 Ripken, above n 31, 186.

84 Ibid, 186; Levenson, above n 48, 68 .
} 
their clients, the document generally concentrates on the disclosure of information required by law, rather than helping potential investors to make a prudent decision. The reason for such trickery is quite understandable in that, a prudent investment decision may not support purchasing financial products having poor economic fundamentals. Commenting on this insufficiency, Levenson, a former director of the US-SEC Corporate Finance Division, said that new concepts of disclosure must be worked out and this is doable and 'must be done'. ${ }^{85}$

Reliance on flawed assumption of investors' rational behaviour: One of the most significant weaknesses is that the BDR relies on a flawed assumption that investors are purely rational actors who are able to logically process the disclosure effectively to make best investment decisions. ${ }^{86}$ Friedman in 1953 stated that the fundamental assumption of modern finance theory is that market movement is reliant upon rational expectations in which prices are set by rational investors. ${ }^{87}$ Recent empirical and experimental studies refute this claim of rational behavior of investors. ${ }^{88}$ There is a tendency that investors move in the same direction at a time regardless of the economic fundamentals of securities that underlie their investment decision. ${ }^{89}$ Investors are overconfident about their ability to escape the bubbles before they burst. ${ }^{90}$ This overconfidence seems to be more dangerous than ignorance in that the former deter people away from being educated or seeking professional advice. ${ }^{91}$ Giving emphasis to education, the Organisation for Economic Cooperation and Development (OECD) defines financial education as:

The process by which financial consumers/investors improve their understanding of financial products, concepts and risks and, through information, instruction and/or objective advice,

\footnotetext{
${ }^{85}$ Levenson, above n 48, 68.

${ }^{86}$ Ripken, above $n$ 31, 147-48.

${ }^{87}$ Milton Friedman, 'The Methodology of Positive Economics' in M Friedman, Essays in Positive Economics (University of Chicago, 1953) 3.

${ }_{89}^{88}$ Avgouleas, above n 12, 28.

89 See Kern Alexander et al, 'Financial Supervision and Crisis Management in the EU' prepared for the European Parliament's Committee on Economic and Monetary Affairs' IP/A/ECON/IC/2007-069 (Dec 2007) 3-7.

${ }^{90}$ See, for details, Gallery and Gallery, above n 12; Robert J Shiller, 'Measuring Bubble Expectations and Investor Confidence' (2000) 1 Journal of Psychology and Financial Markets 49.

${ }^{91}$ See Gallery and Gallery, above n $12,36$.
} 
develop the skills and confidence to become more aware of financial risks and opportunities, to make informed choices, to know where to go for help, and to take other effective actions to improve their financial well-being. ${ }^{92}$

Expressing a similar view, Australian Securities and Investments Commission (ASIC) observes that although full disclosure is essential for informed decision, adequate financial literacy is imperative for the disclosure regime to be effective. ${ }^{93}$

For the sake of argument even if it is conceded that disclosures are full and fair as required by law and as expected by a reasonable ordinary investor, there is a real problem of 'strong pervasive cognitive and motivational distortions' that affect fair consideration of the information disclosed and assessment of relevant risks. ${ }^{94}$ This behavioural constraint makes the disclosure useless to most of the ordinary investors and undermines investor protection under the DBR. ${ }^{95}$ This casts doubt about the usefulness of disclosure as the optimal regulatory philosophy, 'if most investors suffer from cognitive biases' ${ }^{96}$

Given the above weaknesses of the DBR that evidently impede the communication of material information by issuers to investors, the achievement of Roosevelt's claim of substitution of the doctrine of caveat emptor (DCE) by its opposite doctrine of caveat venditor (DCV) is questionable. The following discussion demonstrates that despite the substitution in law, the DCE still prevails in the financial market in practice.

\section{Disclosure Philosophy and the Doctrine of Caveat Emptor}

A brief discussion of the DCE seems pertinent to an adequate understanding of the ineffectiveness of the DCV in the financial market. The DCE originated in ancient Rome to

92 OECD, Improving Financial Literacy: Analysis of Issues and Policies (OECD Publishing 2005) 13-14. See, for detail of the importance of financial literacy, OECD, 'The Importance of Financial Education' Policy Brief (Jul 2006) http://www.oecd.org/dataoecd/8/32/37087833.pdf.

${ }_{93}$ Australian Securities and Investments Commission, PJC Inquiry into Financial Products and Services in Australia: Submission by the Australian Securities and Investments Commission (August 2009) 75078 http://www.apesb.org.au/uploads/attachment-4-c-asic-submission-to-pjc-inquiry.pdf.

${ }_{94}$ Elaine A Welle, 'Freedom of Contract and the Securities Laws: Opting Out of Securities Regulation by Private Agreement (1999) 56 Washington and Lee Law Review 519, 583.

${ }^{95}$ Choi and Pritchard above n 1, 42.

${ }^{96}$ Ibid, 22. 
protect the silent sellers of residential real estates and it was quickly adopted in England in the $16^{\text {th }}$ century. ${ }^{97}$ Hence the civil law had created and the common law had imported this doctrine which dominated the commercial transactions for a long period of time until the advent of the modern DCV. ${ }^{98}$

As held by the Texas Supreme Court in Humber $v$ Morton, the common law DCE 'was fundamentally based upon the premise that the buyer and seller dealt at arm's length, and that the purchaser had means and opportunity to gain information concerning the subject matter of the sale, which [means and opportunity] were equal to those of the seller'. ${ }^{99}$ Similarly, the Supreme Court of Washington in Frickel v Sunnyside Enterprises Inc maintains that the doctrine presupposes that the buyer has equal access to the information about a real estate as both the buyer and seller have the same capability, means and opportunity to check the property. ${ }^{100}$ Thus this doctrine assumed equal bargaining powers of both buyers and sellers of a real estate and protected the seller from any defects in the property where the seller remained silent. A seller could be charged only if they had engaged in misrepresentation which was relied upon by the buyer. Reliance in this respect means refraining from inspecting the property for any potential defects based on the misrepresentation conveyed by the seller. ${ }^{101}$ The seller was privileged to remain silent, hence silence was the key safeguard under the DCE in the absence of a fraudulent act or misrepresentation.

The 'assumption' of equality between buyers and sellers proved incorrect especially during the housing boom following World War II when numerous instances of sales of poor

\footnotetext{
${ }^{97}$ See Nicola W Palmieri, Good Faith Disclosure Required During Pre-contractual Negotiations (1993) 24 Seton Hall Law Review 70, 110.

${ }^{98}$ Leo Bearman Jr, 'Caveat Emptor in Sales of Reality - Recent Assault upon the Rule (1961) 14 Vanderbilt Law Review 541, 542.

${ }^{99} 426$ S.W.2d 554, 557 (1968).

${ }^{100}$ See Frickel v Sunnyside Enterprises Inc 725 P 2d 422, 425 Wash (1986).

101 Alex M Johnson Jr, 'An Economic Analysis of the Duty to Disclose Information: Lessons Learned from the Caveat Emptor Doctrine' (2008) 45 San Diego Law Review 79, 106.
} 
quality houses rose significantly. ${ }^{102}$ Inexperienced and unsophisticated homebuyers who bought defective houses sued their respective sellers for a legal remedy believing that the sellers provided implied warranty of habitability, even though the DCE had governed all the real estate conveyances. ${ }^{103}$ Having been inundated with numerous lawsuits lodged by the innocent homebuyers, the courts tried to find out an exception to the prevalent rule of caveat emptor in a quest for justice for both parties to the litigations. ${ }^{104}$ Thus, the courts started relying on the pro-consumer doctrine, the DCV, in deciding the cases instituted by the homebuyers. For example, in 1957 the Ohio Circuit Court of Appeal in Vnderschrier $v$ Aaron $^{105}$ applied the implied warranty of fitness for habitation by supplanting the DCE to a contact between a builder-seller and the original buyer of a residential property.

The philosophical underpinning of the civil law DCV, as observed by the Supreme Court of Texas, is that the price must be consistent with the quality of the goods sold, and selling the product implies that they have a value. ${ }^{106}$ The Texas Court of Civil Appeal held by way of dicta in 1944 that ' $[\mathrm{b}] \mathrm{y}$ offering the house for sale as a new and complete structure appellant impliedly warranted that it was properly constructed and of good material and specifically that it had a good foundation'. ${ }^{107}$ This implied warranty is a warranty of habitability which is interchangeable with several words such as fitness, workmanlike construction, quality, or suitability. ${ }^{108}$

The doctrine of implied warranty is not a new concept as it was originally applied by the US Supreme Court in 1884 in Kellogg Bridge Co v Hamilton ${ }^{109}$, which was first followed by

\footnotetext{
${ }^{102}$ Bearman, above n $98,542$.

103 Ibid.

${ }^{104}$ Ibid, 542-543.

105140 N E 2d 819 Ohio Ct App (1957)

${ }^{106}$ Humber v Morton 426 S.W.2d 554, 557 (968).

${ }^{107}$ Loma Vista Development Co. v. Johnson, 177 S.W.2d 225 Tex Civ App (1943).

${ }^{108}$ See Jane P Mallor, 'Extension of the Implied Warranty of Habitability to Purchasers of New Homes' (1982) 20 American Business Law Journal 361, 361.

${ }^{109} 110$ U S 108, 111 (1984).
} 
the Court of Appeals of Ohio in Vnderschrier v Aaron. ${ }^{110}$ This doctrine of implied warranty gained popularity in the US during the $1960 \mathrm{~s}$ and $1970 \mathrm{~s},{ }^{111}$ and it is now believed to be a dominant rule for commercial transactions all over the developed world. The doctrine postulates that inexperienced ordinary homebuyers are generally forced to rely on the skill and experience of a builder-seller in purchasing new homes as decided by numerous cases in the United States. ${ }^{112}$

Although the US Supreme Court applied the doctrine of implied warranty of habitability under the DCE in 1884, which had been subsequently followed by majority of the state courts, the courts restricted the application of this doctrine to the sale of a new home by builder-vendor. ${ }^{113}$ In other words, the warranty could be claimed by only the homeowner who had bought it from the builder-vendor, therefore, the used homebuyers were not entitled to make such a claim against the builder under common law. ${ }^{114}$ However, the used homebuyers began experiencing some success against the builders for latent defects of a home in the late 1960s and 1970s. ${ }^{115}$ In Barnes v MacBrown \& Co, the Supreme Court of Indiana declared that the traditional requirement of privity of contract outdated and extended the implied warranty of habitability to subsequent owners of a home for latent defects which was discovered after the purchase. ${ }^{116}$ The Court described 'latent defects' as being the faults that could not be discovered by purchasers of used homes by conducting a reasonable inspection because the defects became apparent after the sale. ${ }^{117}$ The Court also set out the standard of

\footnotetext{
${ }^{110} 140$ N E 2d 819 Ohio Ct App (1957).

${ }^{111}$ Peter J Shedd, 'The Implied Warranty of Habitability: New Implications, New Applications' (1980) 8 Real Estate Law Journal 291, 293.

${ }^{112}$ See, for example, Frickel v Sunnyside Enterprises Inc 725 P 2d 422, 425 Wash (1986); Schipper v Levitt \& Sons Inc 207 A 2d 314, 325-326 N J (1965); Yepsen v Burgess 525 P 2d 1019, 1022 Or (1974); Bethlahmy v Bechel 415 P 2d 698, 710 Idaho (1966).

${ }^{113}$ Sean M O'Brien, 'Caveat Venditor: A Case for Granting Subsequent Purchasers a Cause of Action Against Builder-Vendors for Latent Defects in the Home' (1995) 20 Iowa Journal of Corporation Law 525, 529-530. ${ }^{114}$ Ibid, 530.

${ }^{115}$ See, for example, Kreigler v Eichler Homes Inc, 74 Cal Rptr 749 (Cal Ct App 1969); Barnes v MacBrown \& Co, 342 N E 2d 619 (Ind 1976); Steinberg v Coda Robertson Construction Co, 440 P 2d 798 (N M 1968).

${ }^{116} 342 \mathrm{~N}$ E 2d 619, 619 Ind (1976).

117342 N E 2d 619, 619 Ind (1976).
} 
reasonableness which requires consideration of the relevant circumstances that included factual determinations of the age of the property and its maintenance and actual use. ${ }^{118}$ The Court imposed the onus of proof on appellants to show that the defect originated with and was caused by the respondent as a builder-vendor. ${ }^{119}$ The DCV is now being popularly adopted by many states to protect both the original and subsequent homebuyers. ${ }^{120}$

\section{Application of the Doctrine of Caveat Emptor - From Real Estates to Manufactured Products}

Although the DCE was initially created to govern the real estate contracts as discussed above, the doctrine had been widely used for the purchase of personal properties such as manufactured goods and chattels around the world. However, presently it has disappeared from the markets of consumer goods. ${ }^{121}$ This disappearance largely owes to the industrial revolution which contributed to the manufacturing of varieties of products that are complicated for consumers to discover the defects by a reasonable inspection. ${ }^{122}$ Consequently, the implied warranties of merchantability and fit for the purpose which are now generally provided to the buyer emerged basically as an exception to the DCE. ${ }^{123}$ However, consumers have gradually become accustomed to buying manufacturing products with these implied warranties in the market place as these are now well entrenched in the consumer protection laws all over the developed world. Hence, the DCV rather than the DCE is now the dominant rule in the markets of manufactured products.

\footnotetext{
118342 N E 2d 619, 619 Ind (1976).

119342 N E 2d 619 Ind (1976)

${ }^{120}$ For detail of the trend towards the adoption of the doctrine of caveat venditor, see Robert L Cherry Jr, 'Builder Liability for Used Home Defects (1989) 18 Real Estate Law Journal 115, 138. For a detailed discussion of the rationale for the adoption of this doctrine for subsequent homeowners, see O'Brien, 'above $n$ 113.

${ }^{121}$ Bearman, above n 98, 542 .

122 Ibid.

${ }^{123}$ Ibid.
} 


\title{
Application of the Doctrine of Caveat Venditor - From Manufactured Products to
}

\section{Financial Products}

Theoretically, the disclosure philosophy, as alluded to earlier, was introduced as substitution for the caveat emptor in financial markets. But, practically, that very purpose has not been achieved to date as perhaps best evident from the GFC. Introducing this philosophy in the US in 1933, President Roosevelt said:

\begin{abstract}
The public in the past has sustained severe losses through practices neither ethical nor honest on the part of many persons and corporations selling securities. ... There is, however, an obligation upon us to insist that every issue of new securities to be sold ... shall be accompanied by full publicity and information, and that no essentially important element attending the issue shall be concealed from the buying public. This ... adds to the ancient rule of caveat emptor ... the further doctrine: 'Let the seller also beware' [caveat venditor]. It puts the burden of telling the whole truth on the seller. It should give impetus to honest dealing in securities and thereby bring back public confidence. ${ }^{124}$
\end{abstract}

The US Supreme Court interpreted the purpose of the disclosure philosophy in the same way that Roosevelt intended. The Supreme Court in the seminal case of SEC v. Capital Gains Research Bureau, Inc noted that 'a fundamental purpose [of the US federal securities laws] was to substitute a philosophy of full disclosure for the philosophy of caveat emptor and thus to achieve a high standard of business ethics in the securities industry. ${ }^{125}$

The above assertions of President Roosevelt who was one of the main architects of the US disclosure philosophy and the interpretations of the US Supreme Court clearly outlined that, a critical purpose of this philosophy was to enable investors to protect themselves by making informed and prudent investment decisions. It aimed to ensure the disclosure of the 'whole truth' and to achieve 'a high standard of business ethics' as suggested earlier. Now the question is whether those objectives of the disclosure philosophy have been achieved.

\footnotetext{
${ }^{124}$ Quoted in H.R. Rep. No. $73-85$ (1933) 2.

125375 U.S. 180,186 (1963).
} 
The causes of the GFC as discussed earlier suggest that neither the issuers of securities disclose the 'whole truth', nor the investors understand or utilise the disclosure made to them for informed investment decisions. As a result, the fundamental objective of investor protection has been compromised as observed in a recent International Monetary Fund (IMF) study which finds that the new origination and funding technology have attempted to stabilise the financial system by compromising the effectiveness of consumer protection. ${ }^{126}$ Even financial stability is seriously diminishing as can be inferred from the ongoing debt crisis in Europe and the financial market volatility across the globe.

The need for the DCV is increasingly gaining popularity from the manifested failures of the DBR to provide investor protection. A recent study conducted by Sandeberg on Scandinavian countries (Denmark, Finland, Norway and Sweden) shows a trend towards the adoption of the DCV in place of the previous DCE. ${ }^{127}$ Sandeberg concludes that the courts in the Scandinavian countries have realised that imposing all investment risks upon securities investors is unreasonable. ${ }^{128}$

This is a widely accepted fact that general investors are mostly driven by rumours than any material information disclosed by the issuer of securities. The GFC suggests that not only the general investors or speculators who play a crucial role in maintaining liquidity in the market, but the institutional investors did not rely on the disclosed information. This is so because the institutional investors borrowed money from banks and then invested in the toxic financial assets which were 'sliced and diced' into CDOs of CDOs, or CDO 'squared' or CDO 'cubed'. ${ }^{129}$ Sandeberg asserts that general investors rarely rely solely on the disclosure

\footnotetext{
${ }^{126}$ Kiff and Mills, above n 30, 1.

${ }^{127}$ For details, see Catarina af Sandeberg, 'From Caveat Emptor to Caveat Venditor - the Winding Road to Prospectus Liability' (2003) Journal of Business Law 91.

${ }^{128}$ For details, see ibid, 101.

${ }^{129}$ Gall, above n 26, 7. See also Satyajit Das, Traders Guns \& Money - Knowns and Unknowns in the Dazzling World of Derivatives (2006) Edinburg: Prentice Hall 279.
} 
made by the issuers. ${ }^{130}$ The amount of losses suffered by European banks from securities derivatives is bigger than that of the US banks largely because of the transfers of the risks by the latter through securitisation of loans to the former. Global banks reported in 2007-2008 their total credit losses of US\$387 billion, of which European banks absorbed US $\$ 200$ billion, whereas the US financial institution suffered only US\$166 billion. ${ }^{131}$ So, the US originators of bad loan successfully fooled the European banking institutions which had recruited experienced financial advisors for their investment analysis. Referring to this foolish investment behaviour, Gall comments that many buyers and sellers vaguely understood the contracts of derivative products that are created using 'exotic mathematical formulae'. ${ }^{132}$ Greenspan, ${ }^{133}$ defending his standing on the long time low interest rates since 2001, said that 'I've been chagrined at how badly some of the judgments of very sophisticated investors have been with respect to risks'. ${ }^{134}$ It is generally argued that the financial institution failed to efficiently manage the risks they assumed. The issue of risk management comes after the proper assessment of relevant risks. The present writer believes that both the loan originators and the investing institutions failed to assess the risks they assumed in the first place, and at the same time, regulators also failed to prevent taking that excessive risk by the market actors.

Schwartz, referring to the creation of derivatives by banks to transfer the risks of holding NINJA debts for a long time, argues that '[s]hifting risk that is the basic property of derivatives has become so complex that neither the designers nor the acquirers of the derivatives apparently understand the risks they impose and implicate derivative owners in

\footnotetext{
${ }^{130}$ Sandeberg, above n $127,101$.

131 Gall, above n 26, 12.

${ }^{132}$ As quoted in ibid.

${ }^{133}$ Alan Greenspan is the immediate past chairman of the US Federal Reserve and he held the position from $1987-2006$

${ }^{134}$ As quoted in Gall, above n 26, 10.
} 
risky contingencies they did not realise they were assuming. ${ }^{135}$ She terms the financial engineers who invented securitisation of mortgage loans as the chief culprits of the GFC. ${ }^{136}$ She adds that securitisation spreads over almost all sorts of debts ranging from mortgage loans to credit card receivable. ${ }^{137}$ Even European banks were unable to assess the risks they took by investing in those securities as evident from their huge loss and the subsequent advice of the EU to their banks not to invest in securities where they would not be able to properly assess the underlying risks. ${ }^{138}$ It is now said that 'securitisation' has become synonymous to mere 'financialisation' 'whereby the value of financial assets exceeds that of tangible assets'. ${ }^{139}$ Giving an example showing the unproductiveness of securitisation, it has been argued that securitisation was created as a vehicle to distribute risks in and comfort the financial system, but it is now spreading fear instead. ${ }^{140}$ The so-called DBR is the prime catalyst of all these exploitations by unethical and unscrupulous lenders and resultant devastations of investors. Dallara, Managing Director of the Institute of International Finance, spells out that:

It is clear that changes need to be made to the disclosure regime but this should not be a matter of seeking more disclosure, but more useful disclosure. It is imperative for regulators, in dialogue with industry, to come up with a disclosure regime that is risk-based and efficient. ${ }^{, 41}$

The forgoing discussion of effectiveness of the DBR suggests that the disclosure philosophy has failed to introduce the DCV in securities markets as intended by its creators.

\footnotetext{
${ }^{135}$ As quoted in ibid, 7

136 Ibid.

${ }^{137}$ Ibid.

138 'European Commission Proposes Further Revision of Banking Regulation to Strengthen Rules on Bank Capital and on Remuneration in the Banking Sector' (August 2009) Corporate Law Bulletin (No. 143) (Melbourne University, Australia).

${ }^{139}$ Mervyn K Lewis, 'The Origins of the Sub-prime Crisis: Inappropriate Policies, Regulations, or Both?' (2009) 33 Accounting Forum 114, 115. See also E Heilpern, C Haslam and T Andersson T (2009) 'When It Comes to the Crunch: What are the Drivers of the US Banking Crisis?' (2009) 33 Accounting Forum 99.

${ }_{140}$ Claudio Borio, 'The Financial Turmoil of 2007- ?: A Preliminary Assessment and Some Policy Considerations', BIS Working Papers No 251, Bank for International Settlements, Basel, March $(2008) 11<$ http://www.bis.org/publ/work251.pdf $>$.

${ }^{141}$ Charles Dallara, 'Structure of regulation: Lessons from the Crisis. A View from the Institute of International Finance (IIF)' (2008) 4 Journal of Financial Stability 338, 340.
} 
Consequently, the DCE still dominantly persists in the financial markets in practice. It can therefore be concluded that the DBR may not be the best strategy any longer to protect investors given the complexity of the recently proliferated financial derivatives. Investor protection is and should remain the first priority of securities regulation all over the world. From this point of view, time is ripe for a reconsideration of the efficacy of the prevalent disclosure regulation and reinvention of the need for a sort of merit regulation in securities

markets.

\section{Conclusions}

Presently it is inherently difficult to distinguish between good and bad ventures in the business world. ${ }^{142}$ Given the stripped exposure of investors to 'excessive sunlight' in securities markets, time is ripe to bring them under a protective shadow in order to protect them from 'skin cancer' as Justice Brandies foresaw in 1913 while advocating the disclosure philosophy. This shadow should come from the government, meaning more substantive regulation instead of extending the list of disclosure requirements. Governments around the world have already been involved in a greater role of more direct intervention through various measures such as bailout, guarantees of deposits, stimulus package etc. ${ }^{143}$ While these measures have proved effective in minimising the devastation of the crisis to some extent on a temporary basis, they are ineffective in preventing the recurrence of such future debacles. Therefore this sort of governmental action can be regarded as a temporary remedy, but certainly 'not a cure in and of itself' as observed by many economists. ${ }^{144}$ A new regulatory scheme must clearly concentrate on the control of distribution of risks in the global

\footnotetext{
${ }^{142}$ George A. Akerlof, The Market for "Lemons": Quality Uncertainty and the Market Mechanism, (1970) 84 Quarterly Journal of Economics 488, 500.

143 Omarova, above n 5, 164.

${ }^{144}$ See Mitchell H Rubinstein, 'Obama's Big Deal: The 2009 Federal Stimulus - Labor and Employment Law at the Crossroad' (2009) 33 Rutgers Law Record 1, 11.
} 
markets. ${ }^{145}$ It is to be borne in mind that prudent risk-taking is more important than carefully managing the risks taken unwittingly.

Financial innovations and proliferations that aim to camouflage the risks inherent in the relevant innovative products should be strictly regulated through paternalistic assessment of merits of derivative debt products by regulators. We do not need the boom in asset prices, ${ }^{146}$ rather booms are needed in the asset themselves - asset price boom is a serious factor of the current crisis. ${ }^{147}$ Recently the European Commission has put great emphasis on the need for investor protection, which requires its member states to 'enact serious investor protection measures' which is essential to creating and maintaining public confidence in the market. ${ }^{148}$ The Commission identifies the scrutiny of prospectuses as one of the central tasks for investor protection. ${ }^{149}$

We are conscious that inappropriate regulation or overregulation can cause more harm than good by making the securities transactions more cumbersome and impair the efficient operation of financial systems. ${ }^{150}$ But we adhere to the assertion of Schwarcz who says that:

The complexities of modem investment securities can lead to a failure of investing standards and financial-market practices for several reasons: these complexities impair disclosure; they obscure the ability of market participants to see and judge consequences; and they make financial markets more susceptible to financial contagion and also more susceptible to fraud. $^{151}$

Central to investor protection under a disclosure regime is 'full and fair disclosure' and investors' ability to aptly process that disclosure for their informed investment decisions. The rationale for the DBR is that investors are adequately protected when all pieces of material information concerning relevant securities are fully and fairly disclosed, because such a

\footnotetext{
${ }^{145}$ Omarova, above n 5, 162.

${ }^{146}$ Discussions of the issue of 'boom in asset prices' are not included in this paper in order to keep this piece within a certain word limit, however, it will be separately discussed in another paper .

${ }_{147}$ Grant Kirkpatrick, The Corporate Governance Lessons from the Financial Crisis (Feb 2009) OECD 4.

${ }^{148}$ See Sandeberg, above n 127, 95.

149 See Ibid, 91.

${ }^{150}$ See generally, Gerard Baker, 'More Regulation will Harm, Not Help, Recovery' The Times (Sept 19, 2008) UK 32; Nancy Funkhouser, 'Reining in on Mortgage Brokers: The Need to Enforce Existing Regulations' (2010) 64 University of Miami Law Review 1145.

${ }^{151}$ Schwarcz, above n 10, 220.
} 
disclosure enables investors to evaluate investment merits of public offers and fend for themselves. ${ }^{152}$ But the foregoing discussion reveals that disclosures are neither fair nor full in many instances. In addition, investors are either ignorant or careless of such disclosure. As a result, a disclosure regime has little positive impact on investor protection which is a core objective of securities regulation. Enabling investors to carry out a merit assessment is the main thrust of disclosure, but such an intended ability of investors is in practice more an illusion than a reality. It is therefore widely accepted that disclosure alone is not enough to protect investors from investing in worthless securities. ${ }^{153}$

As argued earlier, although the substitution of the pro-seller DCE with the pro-buyer DCV was the stated purpose of the introduction of the DBR in the USA, the market reality demonstrates that the DCV exists only in theory and the issuers of securities are still enjoying the benefits of the DCE in practice in detriment of investors.

More substantive regulation of the issuer alone may not produce sustainable improvement in investor protection, as changing the behavioural pattern of investors is equally needed. It is sometimes argued that most of the causes of the GFC are somehow connected with the behavioural aspects of investors. ${ }^{154}$ This is so because risks cannot be completely eliminated from securities regardless of their types. Investor education is complementary to, rather than substitution for, investor protection as argued in a study by OECD. ${ }^{155}$ Financial education is thus regarded as a key measure for investor protection. ${ }^{156}$

It is to be noted that the suggested merit regulation is meant to be applied to only securitised derivative debt products when issued to the public at large, and the disclosure philosophy should still remain in force for other securities and for private placement of

\footnotetext{
${ }^{152}$ Thomas Lee Hazen, The Law of Securities Regulation ( $4^{\text {th }}$ ed, 2002) § 1.7[5], 28.

153 Robert L. Knauss, 'A Re-Appraisal of the Role of Disclosure' (1964) 62 Michigan Law Review 607, 616; Levenson, above n 48, 62-63.

${ }_{155}^{154}$ Avgouleas, above $\mathrm{n} 12,28$.

${ }^{155}$ OECD, 'Improving Financial Education and Awareness on Insurance and Private Pensions' (2008) OECD Publishing 105.

156 Gallery and Gallery, above n 12, 38 .
} 
securitised products. This appears to be a trade off between the development of financial innovations and protection of investors. It means that the protection of investing public, rather than the prevention of the proliferation of financial derivatives, is the ultimate objective of this endeavour. This protection is imperative to restoring and maintaining confidence in the financial system. ${ }^{157}$

Given the sophistication of manufacturing products brought forth by the scientific and technological developments over the past few decades, the DCV tied with a set of specific warranties (merchantability, fit for the purpose, conforming to description, etc) for a certain period applies to the markets of tangible assets (chose in possession). Similarly, perhaps having regard to the generally acceptable concept of fairness and inherent culpability of human beings connecting with financial benefits, the real estate market extends a cooling off period for the buyer to forgo a contract for sale. Securities are intangible personal property (chose in action). By virtue of their nature and the existence of information asymmetry between the trading parties, securities transactions require a high degree of fairness on the part of the seller and prudence of buyers. This is because, it should not be taken for granted that investors generally are able to process the disclosure and assess the merits of public offers of exceedingly complex securities. Nonetheless, there is no warranty or cooling off period as such in securities markets. Understandably, it would be impracticable to provide any guarantee of profit in the investment market, but a warranty of the value of securities equal to the price at the time of sale is desirable. In other words, a warranty that the offered products are worthy of investment, which is akin to the commonly offered warranty of merchantability for the manufacturing products.

This study agrees with Welle that the issue is to determine the appropriate regulatory structure to be imposed, rather than to engage in the debate of regulation versus free

\footnotetext{
${ }^{157}$ Black, above n $9,1-2$.
} 
market. ${ }^{158}$ Finally, it concludes that the disclosure philosophy for securities regulation has now emerged as more a 'Pandora's box' than a panacea as disclosures remain incomplete, unfair, misleading, incomprehensible and complex to general investors. Although much has been accomplished in financial markets, more remains to be done.

${ }^{158}$ Welle, above n $94,551$. 
